\title{
ANTTROPOLÓGICIAS PPGA
}

ENSAIO FOTOETNOGRÁFICO

A VIDA DE UMA LOUCEIRA KARIRI-XOCÓ

Maiara Damasceno da Silva Santana Universidade Federal da Bahia

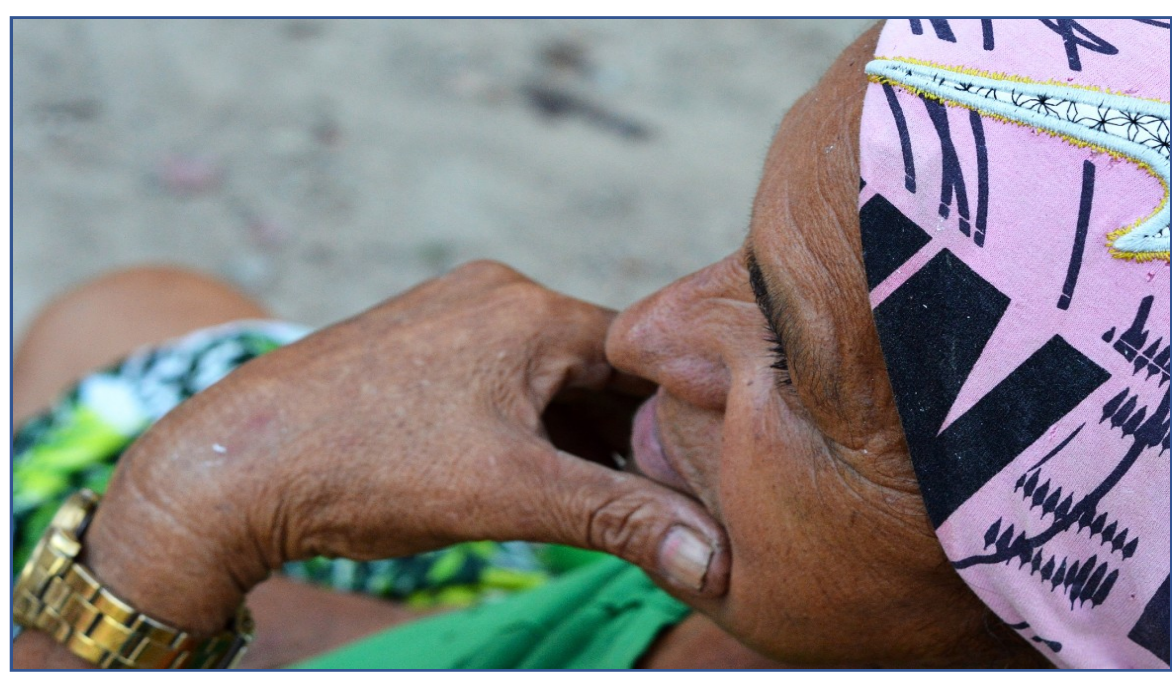

2021

Volume 6, Coleção 2 (n.2)

ISSN: 2525-3781

\section{Sinopse:}

Valdete da Silva, de apelido Dé, é uma indígena Kariri-Xocó de sessenta e quatro anos, reconhecida dentro e fora da aldeia como louceira. São chamadas de louceiras as mulheres, com média de 40 a 65 anos de idade, que fazem panelas, caçarolas, frigideiras, potes e cuscuzeiros de barro, um trabalho considerado como parte de sua "cultura".

As pessoas Kariri-Xocó vivem às margens do Baixo São Francisco, no Nordeste brasileiro, no município de Porto Real do Colégio - Alagoas. Desde 1940, a prática de fabricação das peças de barro, chamadas de louças, já estava voltada exclusivamente para o sustento das famílias, seja por meio da venda e/ou da troca por alimentos, realizadas, principalmente, nas feiras das cidades de Propriá, Maceió, Arapiraca e São Sebastião, em Sergipe e Alagoas.

A fabricação geralmente ocorre entre os meses de outubro, novembro e dezembro. A primeira etapa de produção das peças se inicia com a retirada do barro, em locais chamados de "barreiros". Enquanto caminham em direção aos barreiros, fumam a xanduca (cachimbo) e cantam rojões (cantos de trabalho). Quando encontram as "veias da terra" (o barro bom), utilizam a enxada para a extração do barro. Com a cesta ou lata bem cheia, colocam na cabeça sobre uma "rudia" (rodilha) e assim retornam às suas casas. Algumas dispõem de carro de mão, o que facilita o manuseio e o transporte do barro.

Já em casa, intercalam a quebra do barro com as atividades domésticas. Geralmente, esta etapa é realizada no quintal, sentadas no chão ou em um assento de madeira ou pedra. Depois de quebrado o barro, 
acrescenta-lhe água, amolecendo-o; em seguida, ele é coberto com uma lona ou saco para descansar e o trabalho é retomado no dia seguinte, quando é adicionada a areia peneirada.

Assim que o barro alcança uma consistência macia, iniciam-se os processos de "frojar" (forjar), também conhecido como levantamento das peças em formato cumprido; e "embojar" - modelar as peças em formato redondo. Em seguida, estas são colocadas para secar por dois dias. Uma vez enxutas, recebem a "boca" (parte superior). Adiante, as peças recebem acabamento: são "capiadas" ou "rapadas" (retirada do excesso de barro) com uma "paieta" (palheta), depois "assentadas" com um pano submerso em água e tauá e, em seguida, são "alisadas" com a semente conhecida como "olho de boi” (Leucanthemum vulgare). A derradeira etapa é a queimação, importante para a qualidade e durabilidade da peça. Finalmente, estão prontas as panelas, caçarolas, frigideiras, potes e cuscuzeiros de barro.

O trabalho com o barro é basicamente feminino, mas não exclusivo ao universo das mulheres, os homens geralmente participam das últimas etapas: retirada das lenhas e queimação das peças. $O$ aprendizado para se tornar uma louceira Kariri-Xocó acontece dentro de uma estrutura familiar, por meio de uma rede de parentas(es), sobretudo através da relação entre avós, mães, filhas sobrinhas e afilhadas. Não foi diferente com Dé, que aprendeu o ofício de louceira com a sua mãe, de quem se orgulha muito.

\section{Synopsis:}

Valdete da Silva, nicknamed Dé, is a sixty-four-year-old indigenous Kariri-Xocó, recognized inside and outside the village as a louceira. Women, with an average of 40 to 65 years of age, are called louceiras, who make pots, casseroles, frying pans, pots and couscous pans, a work considered to be part of their "culture".

The Kariri-Xocó people live in the Lower São Francisco, in Northeastern Brazil, in the municipality of Porto Real do Colégio - Alagoas. Since 1940, the practice of manufacturing clay pieces, called dishware, was already focused exclusively on the livelihood of families, either through the sale and/or exchange for food, mainly carried out at fairs in the cities of Propriá, Maceió, Arapiraca and São Sebastião, in Sergipe and Alagoas.
Manufacturing usually takes place between the months of October, November and December. The first stage of production of the pieces begins with the removal of the clay, in places called "barreiros". As they walk towards the "barreiros", they smoke the xanduca (pipe) and sing rojōes (work chants). When they find the "veins of the earth" (good clay), they use a hoe to extract the clay. When they find the "veins of the earth" (good clay), they use a hoe to extract the clay. With the basket or can well filled, they put it on the head on a "rudia" (cloth to put over the head) and thus return to their homes. Some have a wheelbarrow, which facilitates the handling and transport of clay.

At home, they intersperse the breaking of clay with domestic activities. This step is usually performed in the backyard, sitting on the floor or on a wooden or stone seat. After the clay is broken, he adds water, softening it; then it is covered with a tarpaulin or bag to rest and the work is resumed the next day, when the sifted sand is added.

As soon as the clay reaches a smooth consistency, the processes of "frojar" (forging) begin, also known as lifting the pieces in a long-lasting format; and "embojar" - modeling the pieces in a round shape. Then these are put to dry for two days. Once dry, they receive the "boca - mouth" (upper part). Later on, the pieces are finished: they are "capiada" or "rapada" (removal of excess clay) with a "paieta" (pallet), then "assentadas" with a cloth submerged in water and tauá and then "alisadas - smoothed" with the seed known as "ox's eye" (Leucanthemum vulgare). The last step is "Queimação" burning, which is important for the quality and durability of the piece. Finally, the pots, casseroles, pans, pots and clay couscous pans are ready.

The work with clay is basically feminine, but not exclusive to the women's universe, men usually participate in the last stages: removal of wood and burning of the pieces. Learning to become a Kariri-Xocó "louceira" takes place within a family structure, through a network of relatives, especially through the relationship between grandmothers, mothers, daughters, nieces and goddaughters. It was no different with Dé, who learned the craft of "louceira" from her mother, of whom she is very proud. 
Palavras-chave: barro; cultura; louceira; Kariri-Xocó.

Key Words: clay; culture; “louceira”; Kariri-Xocó.

Ficha técnica:

Direção, pesquisa e edição: Maiara Damasceno da Silva Santana - Doutora em Antropologia pelo PPGA/UFBA.

Autores: Gutemberg Santana de Jesus e Maiara Damasceno da Silva Santana. Fotografia e edição: Gutemberg Santana de Jesus.

Datasheet:

Direction, research and editing: Maiara Damasceno da Silva Santana Doutora em Antropologia pelo PPGA/UFBA.

Authores: Gutemberg Santana de Jesus e Maiara Damasceno da Silva Santana.

photography and editing: Gutemberg Santana de Jesus

\section{Autore/as:}

Maria Damasceno da Silva Santana

Universidade Federal da Bahia

https://orcid.org/0000-0001-5406-5748

maiaramerico@gmail.com

Recebido: 8 de agosto de 2021

Aprovado: 25 de novembro de 2021

https://doi.org/10.51359/2526-3781.2021.251964
Este artigo está licenciado sob forma de uma licença Creative Commons Atribuição-NãoComercial 4.0 Internacional (CC BY-NC 4.0), que permite o uso, distribuição e reprodução em qualquer meio, desde que a publicação original seja corretamente citada. A licença não permite o uso para fins comerciais.

https://creativecommons.org/licenses/by-nc/4.0

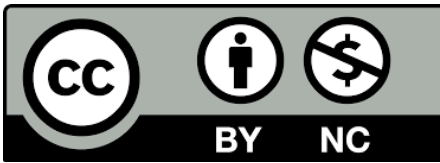

